\title{
FACTORS THAT INFLUENCE THE DEVELOPMENT OF GOVERNMENTAL ACCOUNTING IN MALAYSIA
}

\author{
Zakiah Saleh
}

\begin{abstract}
Governmental accounting is affected by its context, which includes economic development, political stance and individual perceptions. Change and development in government accounting is often associated with public sector reforms. Since accounting is central to the financial management of any organisation, reforms in the public sector would also have an impact on public sector accounting and reporting practices. Accounting and reporting practices need to accommodate the changes in how public sectors are managed. Hence, reforms in governmental accounting and reporting are part of the overall reform in the public sector. As in other countries, the Malaysian public sector has also been undergoing reforms. This study attempts to obtain opinions and perceptions on the factors that have contributed to the development of the Malaysian governmental accounting and on the implications of changing the current accounting system. A total of 20 interviews were conducted with government accountants, government auditors, policy makers and representatives of professional accounting bodies in Malaysia. Unlike in other countries such as Australia, financial crisis did not result in any change to the accounting system in Malaysia. Respondents to the interview survey were of the opinion that the Treasury, including the Accountant General's Department played major roles in the development of governmental accounting in Malaysia. To a lesser extent, the politicians and technological change could also have an impact on the Malaysian governmental accounting. Respondents of the survey are of the opinion that accrual accounting is relevant to the Malaysian governmental accounting.
\end{abstract}

Keywords: Governmental accounting, accounting reforms, accrual basis, Malaysia

\section{Introduction}

Recent developments in governmental accounting have seen a move from cash basis accounting to accrual accounting in developed countries such as Australia, New Zealand and the United Kingdom. The movement towards accrual accounting is also recommended by the International Federation of Accountants (IFAC), an international body concerned with formulating accounting standards (IFAC, 1999). Advocacy of public sector accrual accounting is not entirely a recent phenomenon. The United Nations (UN), the World Bank and the International Monetary Fund (IMF) have all put forward their approval for developing countries to consider the adoption of accrual accounting in the public sector to facilitate the evaluation of their financial aid programmes (UN, 1984; Kopits and Craig, 1998).

As in other countries, the Malaysian public sector has also been undergoing reform. In reviewing the initiatives and experiences of reform in Malaysia, Siddiquee (2006) noted that "...the government of Malaysia has followed the global trend of managerialism and

Corresponding author: Dr Zakiah Saleh, Senior Lecturer, Faculty of Business and Accountancy, University of Malaya (zakiahs@um.edu.my). 
consequently introduced major reforms in various spheres of public bureaucracy and its management." (p. 343). The reform started in the 1960s where the emphasis was on economic and infrastructure development. This was then followed by efforts to improve work systems and procedures in the 1980s, which included the introduction of quality control circles and privatisation policy. In the 1990s, public sector reform in Malaysia was directed towards achieving excellence and quality. The principle strategies include improving systems and work procedures, upgrading the use of information technology, and enhancing accountability and discipline (Hussain, 1998). Malaysia studied the issue of accrual accounting for government in the early 1990s by looking at the development in Australia and New Zealand. Senior officers from the Accountant General's Department (AGD) went to Australia and New Zealand to study the application of accrual accounting for government in the two countries (Annual Reports of the AGD, 1996). However, until now Malaysia is still adopting the modified cash basis of accounting.

In light of the reforms, the following research question is asked: What are the factors that play a role in the development of the Malaysian governmental accounting? This study attempts to obtain opinions and perceptions on the influences or forces that have contributed to the development of the Malaysian government accounting. Specifically, the objectives of this paper are:

1. To seek opinion and perceptions of policy makers, government accountants, government auditors and professionals on the factors that play a role in the development of the Malaysian governmental accounting in the context of the movement towards accrual based accounting.

2. To obtain opinions and perceptions on the impact of changing the current accounting system to the accrual based accounting system.

The remainder of this paper is organised as follows: section 2 provides the literature review, section 3 describes the methodology and section 4 discusses the findings. This paper ends with a summary and conclusion in section 5 .

\section{Literature Review}

One author who is closely associated with attempts to explain why changes in governmental accounting take place is Professor Klaus Lüder. Lüder's contingency model, first outlined in Lüder (1992) and subsequently modified in Lüder (1994) and Godfrey et al. (1996), suggests that accounting innovation can be traced to stimuli, which affect the attitudes and behaviour of users and producers of accounting information (including politicians, administrators and the public). Offsetting these positive forces for change are the implementation barriers. Specifically, in Lüder's contingency model, the transition of one accounting system to another is the dependent variable. The contextual variables, i.e., the independent variables of the model that could explain innovation are as follows (Lüder, 1992, p. 108-109):

1. Stimuli: events that occur at the initial stage of the innovation process and create a need for improved information on the part of the users of accounting information and increase the producers' readiness to supply such information.

2. Structural Variables: characteristics of the social and politico-administrative systems that influence the basic attitudes of users and producers of information towards the idea of a more informative form of public sector accounting.

3. Implementation Barriers: environmental conditions that inhibit the process of implementation, thus hindering, and in extreme cases preventing, the creation of a more informative accounting system that is in principle desirable. 
In 1994, Lüder added the existence of a dominating doctrine into the model and observed two types of innovation process, 'accountabilism-driven' and 'managerialismdriven'. He described both processes as follows (Lüder, 1994, p. 10):

The accountabilism-driven approach is often triggered by some type of financial scandal that results in a demand for more transparent, comprehensive and reliable financial information to be released by the governments. Its main objective is an improvement of governmental external reporting.

The managerialism-driven approach is mainly stimulated by fiscal stress and in the first place is aimed at contributing to more efficient and effective public sector management. This approach, therefore, is primarily concerned with reforming governmental internal (managerial) accounting, but improvements in financial accounting and reporting sometimes is [sic] a by-product of the innovation process.

Although the contingency model was based on a study of developed economies they do offer a starting point for assessing the potential for a switch to accruals accounting by less developed economies.

Change and development in government accounting is often associated with public sector reforms, which is defined by Heeks $(1998$, p. 2) as a "change within public sector organisations (PSOs) that seeks to improve their performance". Hopwood and Tomkins (1984) suggest that reforms came about as a result of economic constraints, which in turn gave rise to demand for improved financial accountability, for efficient use of public sector resources and the need to assess performance, cost and consequences of public sector activities. McCulloch and Ball (1992) also share this view in their assessment of the situation that led to reforms in the government of New Zealand. Government failure has also been attributed to the reforms in the public sector, as found by Wallis and Dollery (2001) in their review of economic theories.

Denning (2000) links advances in technology, apart from responding to political and fiscal pressures, to the reasons for reforms and identified re-engineering, downsizing, privatisation and efforts to deliver services efficiently as the consequences of reforms. Likewise, Hoque and Moll (2001, p. 305) state "a range of social, economic and technological pressures are forcing governments to become more effective, efficient and accountable for the use of publicly generated funds". Since accounting is central to the financial management of any organisation, reforms in the public sector would also have an impact on public sector accounting and reporting practices. Accounting and reporting practices need to accommodate the changes in how public sectors are managed. Hence, reforms in governmental accounting and reporting are part of the overall reform in the public sector.

The analysis of accounting innovation in the government of New Zealand showed that fiscal stress in the 1980s provided the stimulus for reform (Pallot, 1996). Public choice, agency theory and managerialism were the dominant doctrines in New Zealand, resulting in the adoption of a commercial based accounting system. In Australia, as a result of fiscal problems in the 1980s, there were demands for performance reports, new information to help managers focus on cost control, identification of full costs and liabilities, as well as for programmes and performance to be defined in terms of financial matters instead of objective and policy achievements. These demands were met by changing from the cash-based accounting system to accrual-based accounting. The change was successful due to the willingness of the political actors (particularly the Premier) and administrative actor (the 
Treasury) to let management consulting firms and the accounting profession be the "source of advice ... on accounting issues affecting the public sector" (Christensen, 2001, p. 6). Similarly in the UK, in which the environment is favourable to management-oriented governmental accounting, change to accrual accounting was supported by political and administrative structural variables as well as the ability to overcome implementation barriers (Likierman, 1996).

Godfrey et al.'s (1996) made an attempt to widen the sphere of research in governmental accounting to include three Eastern African countries, i.e., Kenya, Tanzania and Uganda. In addition, the study attempted to apply Lüder's contingency model to countries that are "economically less developed and/or with other than democratic political systems" compared to the countries on which the contingency model was originally based (Godfrey et al., 1996, p. 194). The main contribution of Godfrey et al. (1996) was the introduction of the influence of international aid agencies. According to Godfrey et al. (1996), international aid agencies were relevant to the innovation in developing countries' governmental accounting due to their ability to put conditions on their assistance. These agencies could provide additional pressure for political change and require a more comprehensive disclosure of the financial situation, and thus become stimuli. Another variable that was added to the contingency model was "aid distortion" as an implementation barrier. According to Godfrey et al. (1996, p. 201) "the existence on the field of many international organisations and donor agencies, each with its own list of conditions attached to its financial contributions, can result in the implementation of hybrid accounting systems referred to as aid distortion. Aid distortion does hinder the creation of a more informative accounting system".

Studies related to public sector accounting in Malaysia are still lacking and have focused on financial reporting of the local government (Coombs and Tayib, 1997) and the experience of budget reform in Malaysia (Xavier, 1998). Attempts to apply Lüder's contingency model in Malaysia were made by Bujang (1996) when she explained accounting change brought by the introduction of a modified budgeting system in the Ministry of Health in Malaysia. Mohamed (1996) made more extensive use of Lüder's model in her study on accounting policy and financial reporting changes of the privatised Malaysian telecommunications. The current study adds to the body of knowledge by identifying the factors that affect the development of governmental accounting in Malaysia. In addition, the findings of this study will be useful to interested parties, including those responsible for formulating accounting policy and standards, in determining the direction for governmental accounting in Malaysia.

\section{Methodology}

This study adopted the semi-structured interview format where open-ended questions were asked to probe into respondents' reasoning and understanding. It is noted that unstructured interviews may provide more in-depth information (Fontana and Frey, 1998), but the semistructured approach was preferred because it gave the researcher control over time, content and sequence of the interview.

The study employed a non-probability sampling technique to select the interview respondents because the respondents need to have the experience and in-depth knowledge about governmental accounting. The respondents were not chosen randomly; therefore, the sample would not be representative in a statistical sense. However, the nature of the subject matter warrants that the people selected for the study should be able to provide useful and meaningful information. 
The sampling strategy employed in this study is known as purposeful sampling (Patton, 1990). Under this strategy, criterion sampling was employed, selecting only individuals that meet pre-determined criteria. The selection of respondents started with a judgmental sampling, where a decision on who was to be interviewed was made prior to the commencement of the survey. Once the survey commenced, the snowball-sampling strategy was used, which involved identifying more individuals who should participate in the study from the interviewees.

The respondents to the interview survey were selected based on their positions, experience and involvement in governmental accounting and reporting as well as willingness to be interviewed. A total of 24 interviews were conducted. However, the final analysis of results from the interview survey was based on 20 interviews. Four interviews had to be excluded because the interviewees could not provide information on most of the questions being asked. The number of interviewees in each category was as follows:

- Nine interviewees were involved in preparing financial information, all of whom were senior officials from the Accountant General's Department (AGD).

- Four interviewees were involved in making and changing the policy. Two were senior officials from the Treasury, one from the National Institute of Public Administration (INTAN) and one from the Malaysian Administrative Modernisation and Management Planning Unit (MAMPU).

- Three interviewees were senior officials from the National Audit Department (NAD).

- Four interviewees were from the professional bodies - all of them hold senior positions in MASB, MIA and MICPA.

An interview guide was used to ensure that all issues intended for the research were covered in each of the interviews (see Appendix). The interview guide contains outlines or a checklist of the topics and subtopics to be covered during the interviews. The questions included in the interview guide were open-ended to allow respondents to provide opinions and perceptions in their own words. Probes and prompts were used during the interview in order to seek further elaboration and clarifications. Questions for the interviews were developed based on Lüder's contingency model (Lüder, 1992; 1994).

All interview sessions were conducted in the interviewees' offices except one where the interviewee asked to be interviewed in his own home. At the beginning of each interview session, the researcher explained the purpose of the study and the contributions that the interviewees could provide for the study. The interviewees were also given the opportunity to look at the interview guide to ensure that they understood the issues being studied.

Each interview session lasted for at least one hour; some even lasted for three hours. Although the researcher tried to adhere to the sequence of the interview guide, the contents of the interview were largely left to the flow of thoughts of the interviewees. Occasionally, the researcher would probe for more explanation and interrupt the interviewee to ensure that the interview session was on track. Respondents' permission was obtained for tape-recording. The researcher also took hand-written notes during all of the interview sessions.

Data from the interview survey was in the form of tape-recorded and hand-written notes. In order to analyse the interview survey's data, the tape-recorded data were first transcribed. Then both the transcribed data and data from the hand-written notes were analysed and classified into similar categories. Descriptive analysis was made using frequencies and percentages to make inferences about the results.

The discussion of the results includes some quotes from the interview respondents. As the interviewees wish to remain anonymous, they will be identified as interviewee 1 (I-1), interviewee 2 (I-2) and so on. Nine interviews were conducted in the Malay language, which were subsequently translated into English by the researcher. Those quotes, which were translated into English, will be indicated as such in the discussion. 


\section{Discussion of Results}

There have been improvements to the Malaysian governmental accounting and reporting practices in terms of timeliness in producing financial reports and improved quality of reports, as fewer mistakes were made over the years. As gathered by Saleh (2002), improvements to the accounting and reporting practices were related to the modernisation in the government accounting system and increased use of information technology, which are part of the public sector reforms in Malaysia. The accounting and reporting practices were seen to move towards a more management-oriented accounting system, especially with the introduction of the modified budgeting system in 1990 and micro accounting system in 1992. Auditing for the government has also emphasised the economy, efficiency and effectiveness of the use of resources in government activities and programmes.

\subsection{Background Information of Respondents}

The breakdown of interview respondents according to their departments is shown in Table 1. Government agencies include the National Institute of Public Administration (Institut Tadbiran Awam Negara or INTAN) and the Malaysian Administrative Modernisation and Management Planning Unit (MAMPU). Professional bodies include the Malaysian Accounting Standards Board (MASB), the Malaysian Institute of Accountants (MIA) and the Malaysian Institute of Certified Public Accountants (MICPA).

Table 1: Respondents to the Interview Survey

\begin{tabular}{llll}
\hline Organisation & $\begin{array}{l}\text { Number of persons } \\
\text { interviewed }\end{array}$ & $\begin{array}{l}>\text { 20 years } \\
\text { experience in } \\
\text { government sectors }\end{array}$ & $\begin{array}{l}\text { Labels for } \\
\text { interviewees }\end{array}$ \\
\hline Accountant General's Dept. & 9 & 6 & I-1 to I-9 \\
National Audit Dept. & 3 & 3 & I-10 to I-12 \\
Treasury & 2 & 2 & I-13 \& I-14 \\
Government Agencies & 2 & - & I-15 \& I-16 \\
Professional Bodies & 4 & 1 & I-17 to I-20 \\
Total & 20 & 12 & \\
\hline
\end{tabular}

Out of twenty interviewees, twelve (60\%) have had more than twenty years experience working in various sectors in the government. All of the interviewees were holding senior positions within their organisations.

\subsection{Opinions on the Factors that may play a Role in the Development of Governmental Accounting in Malaysia}

In this section, the opinions of interviewees on factors that could influence Malaysian governmental accounting are discussed. During the interview, the researcher sought opinion from interviewees regarding the following factors: the occurrence of financial crisis; the role of politicians; the role of administrators (in the case of Malaysia, the Treasury and AGD); professionalism, specifically the role of professional accounting bodies; technological change; and international bodies. These factors are based on Lüder's contingency model, which was discussed earlier in section 2.

\section{Financial Crisis}

In 1997, along with other Asian countries, Malaysia faced a financial crisis that resulted in a slowdown of the economy and the devaluation of the Malaysian Ringgit. As indicated by Lüder, "research results have confirmed that financial problems serve to trigger reforms of public sector accounting systems" (Lüder, 1992, p. 112). However, in Malaysia, the interview 
survey indicated that the financial crisis had no direct impact on governmental accounting and the following quotations are typical of the responses:

Financial crisis does not create awareness of the deficiencies in the current system. Criticism came from the Auditor General. (I-2, translated)

I am not sure about the impact of financial crisis on accounting. But (when financial problems arise) we are able to give information or feedback to the ministers. (I-3, translated)

During financial crisis, there were questions from members of the cabinet. (But) they don't understand the report, never read and never see the financial statements, (so they have) no interest (in accounting). (I-6, translated)

Directly there is no suggestion that financial crisis has impact on accounting. However, the government is concerned with the long time it takes to make payment to contractors. This has impact on the economy and highlights the need for electronic government and electronic procurement. This may lead to a change in accounting. (I16 , translated)

In relation to Lüder's modified contingency model (1994) on existence of a dominating doctrine, governmental accounting and reporting in Malaysia is not 'accountabilism-driven' since financial stress did not result in any change to the external reporting. Comments from interviewees I-3 and I-16 indicated the need to have better information and the need for electronic government and procurement, which could be inferred as 'managerialism-driven'.

Interviewees were also asked about the factors that they felt played a major role in the development of governmental accounting in Malaysia. Each of them was asked to comment on the factors as indicated in Table 2. Seventeen responded to the questions but not all of them discussed every factor in the question.

Table 2: Analysis of Interviewees Response on Factors that Can Influence Governmental Accounting in Malaysia

\begin{tabular}{llllll}
\hline & Yes & $\begin{array}{l}\text { Qualified } \\
\text { Yes* }\end{array}$ & $\begin{array}{l}\text { Total } \\
\text { 'Yes' }\end{array}$ & No & Not discussed \\
\hline Treasury & 12 & 2 & 14 & 1 & 2 \\
Politicians & 5 & 3 & 8 & 4 & 5 \\
Technological change & 7 & - & 7 & - & 10 \\
International pressure & 2 & 2 & 4 & 9 & 4 \\
Professionalism & 2 & - & 2 & 13 & 2 \\
\hline
\end{tabular}

Notes: Total number of interviewees responded to the question was 17

* Qualified Yes are those who agreed about the importance of the factor given certain condition(s) exist, for examples, depends on individuals or situation.

\section{Treasury}

Most of the interviewees (14 out of 17) felt that the Treasury would play a major role in the development of governmental accounting. Without the backing of the Treasury, no change will take place. During the interview, interviewees from the Treasury department maintained that any change to the accounting systems is under the control of Treasury, as one of the interviewees said: "Treasury has the authority to change, AGD merely handles the bookkeeping" (I-13). Interviewees within the AGD also admitted the authority of the Treasury as well as the NAD and other government agencies as one interviewee indicated: 
"Even if AGD or others decide to change the system, without the Treasury's blessing, change will not take place" (I-15). It is also interesting to note the following comments (from the 'qualified yes' response):

It depends on the top person (in the Treasury). If the person is interested in the issue of accounting, and he or she is informed (either by the Auditor General or Accountant General) of any problems, then he or she will react. (I-5)

Treasury depends on input from AGD. AGD supplies the information then Treasury gives directive for any study or changes to be taken. However, a lot of things depend on the top people. Normally, when the top people change, the preferences also change. (I-6, translated)

\section{Politicians}

Eight interview respondents felt that politicians could play an important role in the development of governmental accounting while four felt otherwise. Among their comments include:

Cabinet plays the most important role in any change, but suggestions may come from the AGD. (I-2, translated)

Sometimes there is influence from the politicians, for example, our Prime Minister initiated the micro accounting system. (I-6, translated)

Politicians are not involved in governmental accounting. (I-9, translated)

Influence from politicians came from the Public Accounts Committee (PAC). However, PAC's comments came from issues raised by our Auditor General, and it is more on the issue of resources instead of the system of accounting. (I-10)

Politicians may give pressure for a change, if they want to. (I-19)

It seems that although politicians could play an important part in the development of governmental accounting in Malaysia, they have not shown any interest so far.

\section{Technological Change}

Seven interviewees indicated that technological change has made an impact on governmental accounting in Malaysia. The interviewees admitted that technology had been used to improve accounting procedures and reporting but had not exerted enough influence to change the system itself.

\section{International Pressure}

As a developing country, Malaysia obtained loans from international bodies such as the World Bank and the International Monetary Fund (IMF). As suggested by Godfrey et al. (1996), it is expected that these international bodies would require Malaysia to practice transparency in its financial reporting and disclosing accounting information on an accrual basis.

Only two interviewees indicated that international pressure has an impact on the development of governmental accounting in Malaysia. They explained their views as follows: Malaysia obtained loans from international bodies including from the World Bank and the IMF. These institutions require specific information and Malaysia must 
respond to their requirements. However, we provide separate reports for these institutions. (I-16, translated)

International bodies' demand for change comes as a result of globalisation effect. When more international players/investors do business in Malaysia, they become stakeholders to the government reports. (I-20)

Based on the above, the fact that the Malaysian government produced separate reports to satisfy the requirements of international agencies supports Godfrey et al.'s (1996) view about aid distortion.

A further four interviewees referred to the role of the IFAC. According to these interviewees, the IFAC's efforts at harmonising the public sector accounting standards did not influence the development of Malaysian governmental accounting.

\section{Professionalism}

Lüder indicated that "if there is an interest of professional organisations in the public sector, a strong interest in the application of private-sector accounting in the public sector can be presumed as well" (Lüder, 1992, p. 114). In Malaysia, there seemed to be very little interest from professional bodies in public sector accounting.

Most of the interviewees (13 out of 17) indicated that professional bodies have not been playing the role to influence Malaysian governmental accounting. When asked about the role of professional bodies in Malaysian governmental accounting, the following are some of their comments:

Government accounting and private sector accounting are different. Professional bodies only deal with private sector accounting. (I-5, translated)

There has been no interest from private sector and also not enough academic involvement. (I-6, translated)

There has been no involvement from the professional bodies. There is no benefit to them. (I-16, translated)

There has been a study conducted by a private firm on government payment system in 1998. Although not directly recommending accrual accounting, the firm indicated about inadequacy of cash accounting in showing financial condition of the government. The recommendation has been put forward to the ministry but there has been no change to the basis. I think there is a lack of involvement from private sector. The professional bodies only concentrate on private companies. (I-19)

All of these comments indicate that the Malaysian professional accounting bodies have not shown interest in the development of governmental accounting. Governmental accounting was seen as belonging to the AGD and the professional bodies only dealt with accounting in the private sector as supported by the following comment:

MASB is established with objective to set accounting standard for the private sector. So far, MASB has not been approached by the AGD to set the accounting standard for the government. But MASB will co-operate with the AGD if invited. (I-18)

\subsection{Impact of Change from Modified Cash to Accrual Accounting}

One of the objectives of this research is to obtain opinions on the issue of adopting the accruals basis for governmental accounting. Interviewees were asked whether Malaysia 
should go for accrual accounting and the implications of changing the current accounting system to accrual accounting.

Out of 19 interviewees, 14 (74\%) agreed that Malaysia should go for accrual accounting while two felt that there should be a study on the applicability of accrual accounting in the Malaysian government. Three interviewees indicated that accrual accounting is not suitable for Malaysia. One of the reasons was the fact that accrual accounting would require the government to disclose information, which may be sensitive to the security of the country. According to one interviewee, accrual accounting would require disclosure of government assets including assets of the defence ministry. Disclosing assets of the defence ministry might indicate the strength of the country, which he considered to be sensitive to the security of any country.

On the other hand, seven interviewees felt that accrual accounting could provide better accountability for the government. One interviewee felt that:

Accrual accounting would be more appropriate even though the simplicity in implementing cash accounting is still the first choice. Since the decision making is a crucial process, comprehensive and precise information is vital. As a result, the accrual accounting is the best basis for any entity including the government. (I-7).

One of the interviewees from the professional bodies had this comment:

Cash accounting is sufficient for accountability. However, accountability is not the only objective of financial reporting. Government needs good long term financial planning. To do this, government needs information on items such as long-term liabilities. This information is not available with the current reporting system. (I-19)

\section{Bodies Responsible for Initiating Change}

When asked who should be responsible to initiate the change to the accounting system, seven interviewees felt that the accounting system of the government was the responsibility of the AGD. A further five interviewees felt that the responsibility was in the hands of the Treasury. However, four interviewees pointed out that the AGD can only initiate the change, approval would still be at the Treasury level.

It was indicated during the interview that Malaysia had previously studied the issue of accrual accounting for government in the early 1990s by looking at the development in Australia and New Zealand. Senior officers from the AGD went to Australia and New Zealand to study the application of accrual accounting for government in the two countries (Annual Reports of the AGD, 1996). However, the issue of accrual accounting for government was not developed further because there was no support from the Treasury for any change to the existing practice. Four interviewees mentioned this in which one of them explained: "At the moment the current system is still able to provide useful information to the policy makers" (I-9-translated).

\section{Accounting Standards}

Changing from cash to accrual accounting would require a different set of accounting standards than the current Treasury Instructions and Circulars. Seven interviewees indicated that the AGD should be the standard setter because the department has a better understanding of the government's accounting requirements. In fact, the AGD has already initiated the standard setting process under the current modified cash accounting in 1995.

It should be noted, however, that eight interviewees who were not from the AGD felt that standard setting for the government should be undertaken by an independent body such as the MASB or by adopting standards issued by IFAC. Some of their views are as follows: 
Standard setter should be an independent body from the regulator (Treasury) and the implementers (AGD). An independent body equivalent to MASB should be set up. (I20).

Government needs to have a standard. Personally, I feel that IFAC's standard should be adopted. If AGD were to set the standard, other parties should be included - the practitioners, auditors, etc. AGD should follow similar process taken by MASB in setting the standard. (I-10).

\section{Problems Associated with Change in Accounting Basis}

The change to accrual accounting would also involve huge costs and according to six interviewees, a cost-benefit analysis is needed before the government makes any decision to go for accrual accounting. Although it was indicated that accounting staff would be sufficient to implement accrual accounting, there could be some resistance due to the likely increase in their workloads. It was also recognised that asset valuation would be a major consideration in implementing accrual accounting.

One interviewee (I-4) also indicated that the size of the Malaysian government might hamper efforts to change the governmental accounting system to an accrual-based system. She further commented that countries such as New Zealand, Australia and Singapore, which have adopted accrual-based accounting, are relatively smaller than Malaysia. A major difficulty would be to trace, value and record assets of the governments.

In terms of qualification of accounting personnel, the National Institute of Accountants, set up by the government, may provide the government with the necessary staff to handle any change in the accounting basis. As indicated by the previous Accountant General, "adequate qualified accounting personnel and trained personnel in accounting and financial management is crucial in the successful implementation of an accounting and financial management system besides having a computerised system of the latest technology" (Osman, 2001, p. 14).

\section{Legal System}

One of the barriers towards a more informative accounting system is the flexibility of the legal system. According to Lüder (1992) the "legal system influences the flexibility of the public accounting system. The tendency is for the system to be less flexible in countries that belong to the Roman-Germanic tradition than in countries with English legal tradition" (Lüder, 1992, p. 118). Malaysia inherited the English legal system, which according to Lüder is flexible. Six interviewees clearly indicated the need to amend the relevant Acts if Malaysia were to adopt accrual accounting. Nevertheless, similar to other interviewees, they also admitted that changing the legal requirements would not be a great obstacle to changing the accounting system.

\section{Summary and Conclusions}

The first objective of this study is to seek opinion and perceptions on factors that could play a role in the development of the Malaysian governmental accounting. Based on an interview survey, it was found that the Treasury, including the Accountant General's Department, played major roles in the development of governmental accounting in Malaysia. To a lesser extent, the politicians and technological change could also have an impact on Malaysian governmental accounting. Unlike in countries such as Australia and New Zealand, financial crisis or fiscal stress did not influence the development of governmental accounting in Malaysia. In addition, international pressures and professionalism were not perceived to be 
major factors in the development. Consistent with Godfrey et al., demand by international organizations and donor agencies were met by implementing a hybrid accounting system. Specifically, in the case of Malaysia, requests for financial information based on accrual basis were met by providing a special report instead of changing the accounting system as a whole.

In view of the development towards accrual based accounting for the public sector, the second objective of this study seeks to obtain opinions and perceptions on the impact of changing the current modified cash basis accounting to an accrual based accounting system. It was gathered from the interview survey that accrual accounting is seen to be relevant to governmental accounting. Interviewees indicated that the quality of financial reports could be improved if assets and liabilities were reported. However, the main problem that hampers the adoption of accrual accounting in Malaysia would be the costs which include costs of training and new infrastructure. Change to accrual accounting should only be adopted if it is financially justified. Other problems include insufficient qualified accountants and the need for training in order to change the use of cash accounting to accrual accounting. Most of the respondents to the interview survey felt that the Accountant General's Department should initiate change but that an independent body should be responsible to set accounting standards for the public sector.

In conclusion, although there were no strong barriers to change the governmental accounting system, the stimuli (financial crisis) and the structural variables (politicians, administrators and professional accounting bodies) have not exerted enough pressure for any change in the accounting system to take place. The Treasury and the AGD seem to have a major influence on the development of governmental accounting in Malaysia. However, any change to the accounting system depends on the accounting and professional background and the interest of the individuals who lead the Treasury. Introduction of a new system also needs strong support from the executives and the politicians. The professional bodies could play a role in promoting the change to accrual accounting.

This study adopted Lüder's contingency model as a framework to investigate the factors that influence the development of governmental accounting in Malaysia. Although the model was initiated in developed countries, this study shows that it is also applicable in a developing country. For future study, some modifications to the variables may be necessary in order to explain fully the development of governmental accounting in Malaysia. Among variables that need to be looked at are the level of economic development and the status of professional accounting bodies in Malaysia.

The conclusions of this study are limited by problems in the method of data collection. There is the possibility of self-selecting bias in which only people interested in the issues of the study were willing to be interviewed. In order to obtain a more comprehensive description and development of governmental accounting in Malaysia, a historiography research could be undertaken. Utilising a systematic content analysis of data, which could be obtained from the Annual Report of the AGD as well as other relevant government publications, could enhance the value of the historiography research. The current study could be further improved by bringing in other people as respondents such as users of the government financial information and professional accountants. Users of financial information may include the creditors, managers of government departments and agencies, and the politicians. Their views may indicate whether or not it is necessary for the government to change the current accounting system. Increasing the number of respondents could enable a more positivist approach and allow for statistical testing of hypotheses. 


\section{References}

Accountant General's Department of Malaysia 1996 Annual Reports. (In the national language)

Bujang, F. (1996) 'Implementation of the MBS in the Malaysian Ministry of Health, with Special Reference to Sarawak General Hospital'. PhD Thesis, University of Aberdeen.

Chan, J.L., Jones, R.H. and Lüder, K.G. (1996). 'Modeling Governmental Accounting Innovations: An Assessment and Future Research Directions'. Research in Governmental Nonprofit Accounting, Vol. 9, pp. 1-19.

Christensen, M. (2001) 'Public Sector Accrual Accounting: Who Made the Emperor's Clothes?' Paper presented at the Third Asian Pacific Interdisciplinary Research in Accounting Conference, Adelaide, Australia.

Coombs H.M. and Tayib, M. (1997). 'Financial Reporting Practice: A Comparative Study of Local Authority Financial Reports Between the UK and Malaysia'. Paper presented at the 6th CIGAR Conference, Milan, Italy.

Denning, M.J. (2000). 'Governments Are Different'. CAMagazine, December, Canadian Institute of Chartered Accountants, pp. 32-34.

Fontana, A. and Frey, J.H. (1998). 'Interviewing: The Art of Science'. In: Denzin, N.K. and Lincoln, Y.S. (eds.) Collecting and Interpreting Qualitative Materials. Thousand Oaks, CA: Sage, pp. 47-78.

Godfrey, A.D., Devlin, P.J. and Merrouche, C. (1996). 'Governmental Accounting in Kenya, Tanzania, and Uganda'. Research in Governmental and Nonprofit Accounting, Vol. 9, pp. 193-208.

Heeks, R. (1998). 'Information Systems and Public Sector Accountability'. Working Paper Series, Paper No. 1. Institute for Development Policy and Management, University of Manchester.

Hopwood, A. and Tomkins, C. (eds.) (1984). Issues in Public Sector Accounting. Oxford: Philip Allen, pp. 1-9.

Hoque, Z. and Moll, J. (2001). 'Public Sector Reform: Implications for Accounting, Accountability and Performance of State-Owned Entities - An Australian Perspective'. The International Journal of Public Sector Management, Vol. 14, No. 4, pp. 304-326.

Hussain, Z.A. (1998). 'Responding to Citizens'. Paper presented at the Workshop on Public Management in Support of Social and Economic Objectives, OECD, Paris.

IFAC (1999). The Development of International Public Sector Accounting Standards: Which Bases of Accounting? [WWW] <URL: http://www.ifac.org/ StandardsAndGuidance/ ExposureDrafts/Public-Sector/IPSAS-Revised/InvitationToComments.pdf> [accessed 15 Jan 2000]

Kopits, G. and Craig, J. (1998). 'Transparency in Government Operations'. Occasional Paper No. 158. Washington D.C.: International Monetary Fund.

Likierman, A. (1996). 'The UK Government's Accounting and Budgeting Revolution'. Research in Governmental Nonprofit Accounting, Vol. 9, pp. 303-322.

Lüder, K.G. (1992). 'A Contingency Model of Governmental Accounting Innovations in the Political-Administrative Environment'. Research in Governmental and Nonprofit Accounting, Vol. 7, pp. 99-127.

(1994). 'The "Contingency Model" Reconsidered: Experiences from Italy, Japan and Spain'. In: Buscher, E. and Schedler, K. (eds.) Perspectives on Performance Measurement and Public Sector Auditing. Berne: Paul Haupt Publishers, pp. 1-15. 
McCulloch, B.W. and Ball, I. (1992). 'Accounting in the Context of Public Sector Management Reform'. Financial Accountability \& Management, 8(1), Spring, pp. 712.

Mohamed, N. (1996) 'Privatisation of Malaysian Telecommunications: Accounting and Reporting Changes'. PhD Thesis, University of Aberdeen.

Osman, S.M. (2001). 'The Development of the Malaysian State and Local Governments Accounting and Reporting - The Role of the Accountant General's Department'. Paper presented at the International Forum for State and Local Governments Accounting and Reporting, Langkawi, Malaysia.

Pallot, J. (1996) 'Innovations in National Government Accounting and Budgeting in New Zealand'. Research in Governmental Nonprofit Accounting, Vol. 9, pp. 323-348.

Patton, M.Q. (1990). Qualitative Evaluation and Research Method. $2^{\text {nd }}$ edition. Newbury Park: Sage.

Saleh, Zakiah (2002). 'Governmental Accounting in Malaysia'. PhD Thesis, University of Wales.

Siddiquee, N.A. (2006). 'Public management reform in Malaysia: Recent initiatives and experiences'. International Journal of Public Sector Management, Vol. 19, No. 4, pp. 339-358.

United Nations (UN) (1984). Accrual Accounting in Developing Countries. New York: United Nations.

Wallis, J. and Dollery, B. (2001). 'Government Failure, Social Capital and the Appropriateness of the New Zealand Model for Public Sector Reform in Developing Countries'. World Development, Vol. 29, No. 2, pp. 245-263.

Xavier, J.A. (1998) 'Budget Reform in Malaysia and Australia Compared'. Public Budgeting \& Finance, Spring, pp. 99-118. 


\title{
INTERVIEW GUIDE OPINION AND PERCEPTION ON THE DEVELOPMENT OF GOVERNMENTAL ACCOUNTING AND REPORTING
}

\author{
IN RECENT YEARS, COUNTRIES SUCH AS AUSTRALIA, NEW ZEALAND AND THE \\ UNITED KINGDOM, HAVE ADOPTED ACCRUAL ACCOUNTING FOR GOVERNMENT \\ FINANCIAL REPORTING. THE FOLLOWING QUESTIONS ATTEMPTS TO SEEK YOUR \\ OPINIONS ON ACCRUAL ACCOUNTING AS THE BASIS FOR GOVERNMENTAL \\ ACCOUNTING AND REPORTING IN MALAYSIA.
}

What can bring about change (i.e. stimuli)?

- Can financial crisis stimulate change to the accounting system?

- Any pressure for change? Dominant doctrines?

- Who reacted to these stimuli, the producers or the users?

- Has there been any indication from the users or interested parties (who way government reports its financial activities? (societal)

Influences:

- What is the role of politicians in governmental accounting?

- What is the role of Treasury in governmental accounting?

- Other person etc.?

- To what extent does private sector accounting profession participate in setting governmental accounting policy? Any meetings or joint discussion?

- Other factors: technological change?

- Who gives pressure for any change in the governmental accounting?

- To what extent will the work of IFAC influences Malaysian governmental accounting (external)

- Any impact of IMF requirements (with regard to national accounts) on governmental accounting policy?

Flexibility of the legal system (barriers)

- How to change the existing requirements

- Is it difficult to change?

- What is the process?

Change to accrual accounting

- What is your opinion on the current accounting system?

- Would you like to see changes?

- In your opinion, should Malaysia go for accrual accounting?

- What need to be changed if Malaysia were to change to accrual accounting?

- Will conversion to accrual accounting provide adequate accountability to legislator and public?

- Will accrual accounting facilitate macroeconomic management?

- Who should be responsible for the implementation?

- What are the costs involved in implementing new system?

- Other implications of accrual accounting?

- Will the existing staff and facilities be sufficient?

- Problems associated with changing attitudes

- Is there a need to have accounting standards?

- Who should set the standards? 